\title{
The Origins of the Income Theory of Money ${ }^{1}$
}

\section{Josef Menšík ${ }^{2}$}

\begin{abstract}
The income theory of money was conceived in the 19th century, and in the first half of the 20th century it formed the backbone of all the main monetary approaches of the time. Yet, since it did so mostly implicitly rather than explicitly, and since the later developments moved economic theory in a different direction, the income theory of money is hardly remembered at present. While mainly accounting for the origins of the approach, I am also offering a brief comparison with the present mainstream economics and I shortly address the question of the possible future of the theory too. The income theory of money explains how nominal prices are formed by interaction of nominal expenditures streams with real streams of goods sold. While various ideas leading to this theory were expressed already by John Law, Richard Cantillon, and JeanBaptiste Say, it is perhaps only Thomas Tooke whom we might want to call the originator of the theory. Within the Classical School of Political Economy, Tooke's ideas were further elaborated by John Stuart Mill. The theory reached a momentous formulation in the works of Knut Wicksell, in many respects a similar exposition was delivered also by Friedrich Wieser. The recognition of the theory was impaired by a change of the mainstream paradigm as well as by a surge in emphasis laid on the quantitative modelling in economics. Yet, there are certain fundamental questions of the monetary theory which the general equilibrium style models cannot cope with, while the income theory of money can, at least to a certain degree. This might give the theory some hope for the future.
\end{abstract}

Key words: Money, Prices, History of Economic Thought, Thomas Tooke, John Stuart Mill, Knut Wicksell, Friedrich Wieser, The Income Theory of Money, The Income Approach to Money, The Income Theory of Prices

JEL Classification: B20, B50, E30, E40, E50

\section{Introduction}

The income theory of money (or the income approach to money, the income theory of prices) exercised considerable influence upon the main approaches to monetary theory of the first decades of the 20th century. It was implicitly present in all of the leading traditions of the time: the Austrian, the Swedish and the Cambridge alike. Indeed, it is hard to even fully understand the monetary theories of such eminent figures as Keynes or Schumpeter without being aware of their income theory of money roots.

\footnotetext{
${ }^{1}$ The contribution was made thanks to the Grant Agency of the Masaryk University project No. MUNI/A/0767/2012.

${ }^{2}$ Masaryk University, Faculty of Economics and Administration, Department of Economics, Lipová 41a, Brno, 602 00, Czech Republic. E-mail: mensik@mail.muni.cz.
} 
At present, the framework of the income theory of money is almost forgotten. The current theory is dominated by the paradigm of general equilibrium and its offshoots. What does it mean for the income theory of money? One of the aims of this paper is to provide an alternative exposition of the fundamental principles of the income theory of money, which will allow for the comparison of this approach with the developments stemming from the general equilibrium approach.

The main objective of the paper, however, is to show the roots of the income theory of money. The classics of Marget (1966 [1938-42]) is still the most comprehensive account of the origins of the income theory of money up till now. The fact is that I am not aware of the existence of any later account of the whole topic whatsoever. My task is thus to use a more recent perspective to provide one. After offering an alternative exposition of the income theory of money I will recast the account of the origins of the income theory of money from the perspective of this reformulation.

Having established the core principles and the historical roots of the tradition, I will be in a position to comment briefly on the loss of popularity of this approach within the present mainstream of economic theory too. At the close the question of the possible future of the theory is shortly addressed.

\section{The Fundamental Principles of the Income Theory of Money}

The income theory of money is a theory of nominal prices. Its aim is to explain the process of the determination of monetary prices in the market economy. It is a flow oriented approach which distinguishes it from the stock orientation of the naive quantity theory of money. On the other hand, it differs from the general equilibrium approach to prices not only in concentration on nominal prices rather than the relative ones, but also in the stress it lays on the market process as compared to the preoccupation with the resulting equilibrium of the general equilibrium approach.

While laying down the principles of the income theory of money, I will try to use concepts familiar to the present economist as much as possible. To start with, it is widely recognized that under usual assumptions, it is only the relative prices which matter to the general equilibrium model. To be more precise, if consumers' choices are to depend solely on individuals' preferences and on the alternatives available to them, and if profit-maximizing firms are price-takers on both product and input markets, then the behaviour of both consumers and firms does not change, if we multiply all prices in the economy by the same constant (Mas-Colell, Whinston, Green 1995 pp. 23, 138-142). It follows that if a certain price vector satisfies the equilibrium conditions, any price vector obtained from it by a scalar multiplication with a positive real number will also satisfy them. This property of the general equilibrium model is sometimes referred to as "the missing equation problem". While the model may determine a set of relative prices necessary for attaining the equilibrium state, the overall level of prices is left undetermined.

The income theory of money is a monetary theory. Its assumption is that all the trade is carried out not in the form of barter but it is rather done in exchange for monetary payments. Instead of imagining a gross exchange of the whole bundles of goods supplied and demanded by the market participants under current prices, the picture is rather that 
of a flow of monetary streams passing through various markets in the opposite direction to the flows of goods. While the ultimate result of the exchange might be the same, the income theory of money is always interested in how it was achieved monetarily, what the actual monetary flows that facilitated the trade were.

If we conceptualize markets in this way, it becomes very easy to specify what the actual average price paid on any of these markets was. We may simply take the volume of the monetary stream which passed through the market in the form of monetary payments, and divide it by the volume of the real stream of goods sold. The total amount paid divided by the total quantity sold yields the average price realized over the given period. This is valid for any single market and the main point of the income theory of money is to consider it, as it were, for the economy as a whole.

The crucial difference from the general equilibrium theory lies in the stress on the market process as contrasted to the state of market equilibrium. It is perhaps best illustrated by the relation of the respective theories to prices under which the trade is allowed to be carried out. While in real economies as well as in the income theory of money framework trade goes on irrespective of whether the actual prices are equilibrium ones or not, the general equilibrium theory explicitly forbids this to happen. It was already Walras (1977 [1871], pp. 40-1) who pointed out that not a single transaction may pass in the general equilibrium model under non-equilibrium prices. If it did, the whole system of equilibrium conditions would get upset. That is why he introduced his concept of "Walrasian auctioneer" and the so called "tâtonnement process". Its sole purpose was to find the equilibrium prices first, and to allow all trade to happen only after. The original as well as the present versions of general equilibrium models are in the end about an exchange of bundles of goods under a fixed set of all prices. The general equilibrium model cannot deal with the trade under non-equilibrium prices because this would require encompassing a sort of time consequence of individual exchange acts which is simply not part of the model's structure. This holds true not only for the discrete time models but even for the continuous time ones.

In an actual economy, obviously, no trade is ever done under completely equilibrium set of prices in existence. The income theory of money is richer than the general equilibrium model in that it allows for this to happen. The manner in which the original authors introduced this aspect into their theoretical system was not without its costs, however. They could do so only at the cost of decreasing the quantitative precision of the theory in question. Their ambition, as compared to that of the general equilibrium theorists, was not to explain quantitatively all the monetary prices. In order to do so, they would have to explain their full development in time too, the complexity of which task was far beyond their imagination, as well as it remains beyond the imagination of present-time general equilibrium theorists. What the income theory of money economist wanted to do was to explain the general structure of the process within which the actual monetary prices are being determined, and the role monetary streams play in this process in particular. This does not necessarily have to include quantitatively exact prediction of any specific nominal prices.

Moving to the primary concern of the income theory of money, let us start with the assumption of the monetary system which is, at least as a first approximation, flexible enough to allow for any level of nominal prices to be achieved monetarily. This means 
that there are no physical limits as to how big or how small nominally the monetary streams may be. There are neither problems of limited divisibility of the monetary unit, nor those of scarcity of the monetary asset in existence, or better the sluggishness of the circulation thereof. Whether the nominal prices are high or low, the monetary system does not introduce any extra cost which should complicate the flow of monetary streams. This is often being subsumed under the concept of endogenous money. Money flows adjust quantitatively to the needs of the economy so as not to hinder the fluency of the economic process.

Monetary economy equipped with a flexible monetary system can operate the same under any price level imaginable. If nominal incomes are high, so will be the prices. If people pay high prices for goods, so will their incomes be. As a parallel to the missing equation problem of the general equilibrium model, this means that with flexible money the price level is ex-ante undetermined. The very same real processes may go on in the economy while the value of its monetary unit may be completely different.

Yet, the ex-ante indeterminacy of the level of prices does not mean one should expect the nominal prices to vary at random. Quite the contrary; if an economy operates smoothly under any actual system of prices, there is a strong tendency of the overall level of prices to persist unchanged. All the individual nominal prices are, it is true, changing according to changes of economic conditions and preferences. Yet they do so as a part of the current system of prices. Even if it is technically possible, we are neither to suppose a coordinated jump of all the prices to let us say double the present level nor, for that matter, to its half either. Also any individual consumer can easily imagine spending double the amount on all goods they purchase should their income double, they will not be inclined to do the former without the latter. Though any company could pay double the wages, had it received double the income for the same amount of goods sold, it will not be inclined to do this wage change of its own. It is a sort of Nash equilibrium we are locked in here, and not a dissimilar one to the Nash equilibrium of the general equilibrium model either. This property of the price system is sometimes referred to as the rigidity of the nominal price system, or simply as the rigidity of prices.

Since there were some misunderstandings in the history about this subject, I deem it proper to look at this point once more and from a slightly different angle. Some incorrect interpretations of the income theory of money read that it is the theory according to which the level of prices is determined by the level of nominal incomes. In fact, it could be thus understood only under very contrived circumstances, such as if all nominal incomes were exogenously decided and paid out by the government or with something along these lines. Usually though, prices are not determined by incomes any more than incomes are determined by prices, and it is a sort of chicken-egg problem to think what came first. The income theorist of money, of course, does understand this mutual relation. Yet, if diversity of factors of productions is smaller than that of consumptions goods, incomes may still keep particular significance in the process. Should we think of labour, for instance, as having a single labour market, then it would be the biggest market of all those considered (leaving the credit and other financial or asset markets aside for the moment that is), any change at this market having substantial influence all over the rest of the economy. This may in a sense justify the sometimes used label of income theory of prices. These remarks on the importance of incomes within the process not- 
withstanding, the income theory of money generally speaking is a theory of monetary process involving the formation of both consumption prices and incomes in the manner of monetary streams and real streams meeting each other, with individual markets and prices playing its role according to the actual setup of the economy in question.

To repeat, even though the price system as a whole shows such a resistance against abrupt changes of the overall level of prices, all individual prices are subject to continuous changes according to variations in economic conditions, preferences, and subsequently in economic decisions. The only thing is that all these changes in individual prices are always conditioned by the present structure of prices. With changing individual prices the price level has to move too, however we prefer to quantitatively measure it. Yet, since the very same factors which tend to increase some prices have as a rule the opposite effect on some other prices, these individual price shifts do in part cancel out. That is why this ongoing process of price adjustments cannot properly account for any strong and persistent trend in the change of all the prices, say a steady growth of the whole price system observable over a period of several months or even of years.

For a secular movement of the price level to occur, there must be a persistent pressure to keep altering either the real or the monetary streams within the economy. Though longlasting repetitive changes in real streams are possible in principle, it will rather be incessant changes originating on the monetary side which will accompany secular movements in the level of prices in practice. Such continual changes of monetary streams are certainly technically feasible with flexible monetary system. To explain them, we need to find some changes in economic conditions for some individuals that will induce them to reorient their behaviour vis-à-vis the monetary streams. They must no longer feel bound by the Nash equilibrium position and they have to keep altering the volume of monetary streams. We shall presently see the various reasons different authors found for this situation to occur.

\section{The Roots of the Income Theory of Money}

Money is but an abstract stream of nominal quantities for the income theory of money. Money is primarily thought of not as a tangible commodity but rather as a random quantifiable entity, perhaps one devoid of any non-monetary uses altogether. This is why the first ideas preceding the income theory of money came about only once the monetary systems began to evolve from purely metallic currencies to systems involving some forms of paper or credit money too.

The man who had intimate personal experience with experiments with a paper currency was John Law (1671-1729). Aside from the disaster he brought on France through the application of his financial schemes, he also wrote a theoretical essay advertising the benefits of paper money called Money and Trade Considered. In this essay Law argues for one of the prerequisites of the income theory of money, which is the theoretical separation of the movement of the values of goods from that of money: "Money is not the value for which Goods are exchanged, but the value by which they are Exchanged" (Law, 1705, chpt. VII).

Richard Cantillon (1680-1734), incidentally one of the few who were able to actually benefit from the Law's experiments, was the originator of several of the key features of 
the income theory of money. His Essay on the Nature of Trade in General (1959 [1755]) has various great merits. He improves on Boisguillebert's model of the real and the monetary circular flows within the economy, coming close to the version later to become the cornerstone of the teachings of the Physiocrats and later still elaborated on as his "schemata of reproduction" by Marx. Cantillon also described the roles of the consumer and the entrepreneur in the economic system, and explained the complex adaptation of the system to changes of the economic conditions, in a way which does not differ from our present understanding too much. His price theory, too, was far ahead of his time. And what is most important for our present purpose, he also laid the basis for the future development of monetary theory.

Cantillon describes the process of monetary expansion starting from increasing nominal income of certain individuals. They, in turn, start to increase nominal demand in certain markets, which leads to increase of respective prices. He is clearly thinking about the streams of money flowing through the economy, using even a parallel to a river here. He explains that prices will be changed according to directions of these streams. This means that monetary expansion brings about changes in relative prices in a way which is hard, even impossible to predict exactly beforehand, as Cantillon maintains. Even the velocity of the circulation of money may change in the process. To sum up, there is no reason why the doubling of the amount of money in this way should lead to the doubling of prices. This famed analysis of the monetary expansion and its results was later dubbed as the Cantillon effect (Cantillon 1959 [1755], pp. 159-81 [211-40]). To quote the most relevant passages directly from Cantillon:

The proportion of the dearness which the increased quantity of money brings about in the State will depend on the turn which this money will impart to consumption and circulation. ... Market prices will rise more for certain things than for others[.] ... [T] he dearness caused by this money does not affect equally all the kinds of products and merchandise, proportionably to the quantity of money, unless what is added continues in the same circulation as the money before ... and that is hardly ever the case. I conceive that when a large surplus of money is brought into a State the new money gives a new turn to consumption and even new speed to circulation. But it is not possible to say exactly to what extent.

(Cantillon 1959 [1755], pp. 179-81 [238-40])

Jean-Baptiste Say's (1767-1832) most famous contribution, the Say's Law of Markets, needs little introduction. What is not so generally recognized, however, is that in the very passages where he explains why the general demand cannot fall short of the general supply, Say also introduces the concept of endogenous money:

There is always money enough to conduct the circulation and mutual interchange of other values, when those values really exist. Should the increase of traffic require more money to facilitate it, the want is easily supplied ... In such cases, merchants know well enough how to find substitutes for the product serving as the medium of exchange or money.

(Say 1880 [1803], p. 56)

Referring perhaps to the practice common in London of his time, where much of the trade was carried out by the means of the bills of exchange, Say highlights the main feature of the endogenous money theory: money does not come to the economic system 
exogenously from without; rather than that, it appears endogenously from within on the demand of the economic system.

\section{Thomas Tooke: From Incomes to Prices and Money}

Thomas Tooke (1774-1858) is the economist whom we might want to call the father of the income theory of money. The reason is that he was the first to consistently link nominal prices to nominal incomes. It is with him, too, that we first find, side by side, both the idea of prices formed by nominal streams meeting the real supplies of goods, and the concept of endogenous money. It is by right that Tooke's monetary theory received some fresh attention from economists recently (cf. e.g. Skaggs 2003, Smith 2001, 2002).

The application of the ideas of the income theory of money is more complicated to the monetary system which is less flexible and somewhat intertwined with some real assets and its market too. This is precisely the case of the gold standard and its various modifications. Tooke is well aware of the difference in the operation of the basic theoretical principles within the gold standard economy as compared to the paper standard one, and he treats these separately.

Tooke argues that it is upon the amount of incomes not on the quantity of money which the nominal volume of demand depends on. And with paper money in place an obvious way how to increase nominal incomes is either to directly hand over newly issued paper notes to civil servants as salaries, or to achieve the same indirectly via various government purchases (Tooke 1844, chpt. XII, pp. 69-71). With flexible monetary system (that is with endogenous money), however, whatever forces set up the level of nominal incomes, prices and money will simply adjust to that. The simple causal chain then runs from the level of incomes to the level of prices and finally to the amount of money. The key points from Tooke's own summary read:

12. That the prices of commodities do not depend upon the quantity of money indicated by the amount of bank notes, nor upon the amount of the whole of the circulating medium; but that, on the contrary, the amount of the circulating medium is the consequence of prices.

13. That it is the quantity of money, constituting the revenues of the different orders of the State, under the head of rents, profits, salaries, and wages, destined for current expenditure, that alone forms the limiting principle of the aggregate of money prices, the only prices that can properly come under the designation of general prices. As the cost of production is the limiting principle of supply, so the aggregate of money incomes devoted to expenditure for consumption is the determining and limiting principle of demand.

(Tooke 1844, Summary of Conclusions, pp. 123-4)

Since we are interested in the monetary part of the picture, this is what is stressed here. It does not mean that Tooke paid no attention to the real side of the supply of goods. Quite the contrary, the cost of production of goods relatively to gold formed the main reason for the prices to change within Tooke's system. Yet, this is relevant for the gold standard system only. With the flexible monetary system, this argument loses all its significance and we are left with the question what might cause substantial change in the circulation of monetary and real streams within the economy, government issuing new money being the obvious culprit. 


\section{John Stuart Mill: Credit and Prices}

John Stuart Mill (1806-1873) was the dominant figure of the latter English Classical School of Political Economy. Though the school is known to be occupied predominantly with the real rather than with the monetary phenomena, Mill's monetary achievements are far from negligible. In particular, Mill explains that it is credit that introduces flexibility into the monetary system and enables the overall level of prices to shift. These very important aspects of Mill's theory sadly seem to escape the attention of present economists.

Although the core of Mill's message might arguably be deciphered already from a single sentence of Tooke, it is Mill who must be credited with the elaboration of this idea. While the sentence in question is rather obscure, and the idea is not well developed elsewhere in Tooke's text, Mill, on the other hand, spends several pages on the same topic delivering a reasonably clear account of what the relation of credit and prices he maintains to be. The sentence of Took alluded to reads as follows:

The prospect of advantage supplies the motive, and the credit of the buyer constitutes the power of purchase.

(Tooke 1844, chpt. XII, pp. 73)

When further elaborating on this point, Mill shows that it is credit in general what constitutes the purchasing power, and it is the use of credit in the payment system that drives the monetary streams within the economy which in turn exercise their influence over the prices. While Tooke presented mainly the obvious way to alter the nominal streams within an economy through the introduction of new paper money passed out in the form of an add-up to the existing incomes, Mill primarily explains a completely different way how to modify the monetary flow. It is a simple change in the use of credit within the payment system which may substantially change the nominal amounts of monetary streams within the economy and subsequently alter the overall level of prices too.

Any time a purchase is made, it always represents a switch from a monetary stream to a goods stream and vice versa. No matter how is the trade settlement organized, once you receive a good for a certain amount of monetary consideration, the two streams have met and the average price on the market was influenced accordingly. And this always requires involvement of a credit of one sort or another in the credit based monetary system. Whether I pay using my own credit or by passing on a credit of someone else, the effect on prices is always the same. The actual form of the credit used is irrelevant here, it is only its volume what counts. In Mill's own words:

What does act on prices is Credit, in whatever shape given, and whether it gives rise to any transferable instruments capable of passing into circulation or not. ... Money acts upon prices in no other way than by being tendered in exchange for commodities. The demand which influences the prices of commodities consists of the money offered for them.... [An buyer] may obtain goods in return for his acceptances payable at a future time; or on his note of hand; or on a simple book credit, that is, on a mere promise to pay. All these purchases have exactly the same effect on price, as if they were made with ready money. 
The amount of purchasing power which a person can exercise is composed of all the money in his possession or due to him, and of all his credit.

(Mill 1965 [1848], III.xii.2, p. 538-540)

[C] redit, though it is not productive power, is purchasing power; and a person who, having credit, avails himself of it in the purchase of goods, creates just as much demand for the goods, and tends quite as much to raise their price, as if he made an equal amount of purchases with ready money.

(Mill 1965 [1848], III.xi.3, p. 530)

It follows from the previous discussion that if multiple agents decide anew to use more credit within the payment system, the total volume of the nominal monetary streams within the economy is bound to increase and, in consequence, so is the overall level of prices. But what might motivate the economic agents to act correspondingly? Mill's answer is explained presently, shortly we will also see a different take on the question as provided by Wicksell.

Similarly to what Wicksell will maintain some 50 years later on, Mill claims that entrepreneurs (the "mercantile public") will introduce new credit into monetary system when they, according to their price calculations, expect to profit from this operation.

The inclination of the mercantile public to increase their demand for commodities by making use of all or much of their credit as a purchasing power, depends on their expectation of profit.

(Mill 1965 [1848], III.xii.3, p. 540)

In Mill's view it is the case of speculation when the use of credit in the payment system is changed substantially. He maintains that more and more credit is used by the speculators for purchases in the payment system particularly when they expect some prices to rise. At the same time, the use of more credit in purchasing causes the increases of actual prices and thus the speculation process feeds back on itself. Mill points out that the speculative rise of a price can happen in any single market at any time. But the use of the new credit in the payment system for the purpose of speculative purchases is the indispensable presumption of this process to happen with respect to "commodities generally" (Mill 1965 [1848], III.xii.3, p. 541).

As far as the start of the speculation process is concerned, it may be caused by any appropriate shift in mercantile expectations. The process is then propagated by an imitation of the success of the first speculators and, as explained above, is enabled and fostered by an expansion of credit:

Some accident which excites expectations of rising prices, such as the opening of a new foreign market, or simultaneous indications of a short supply of several great articles of commerce, sets speculation at work in several leading departments at once. The prices rise, and the holders realize, or appear to have the power of realizing, great gains. In certain states of the public mind, such examples of rapid increase of fortune call forth numerous imitators, and speculation not only goes much beyond what is justified by the original grounds for expecting rise of price, but extends itself to articles in which there 
never was any such ground: these, however, rise like the rest as soon as speculation sets in. At periods of this kind a great extension of credit takes place.

(Mill 1965 [1848], III.xii.3, p. 542)

Mill argues that holders of commodities will find out that their commodities are overvalued eventually, they will start to sell, and a reverse process will ensue that will eventually lead to a collapse of prices. If it is an economy as a whole rather than a single market that we are speaking about, this general collapse of prices is what is known as "commercial crisis" (Mill 1965 [1848], III.Xii.3, p. 539-542). Thus Mill completes his explanation of a speculative, credit-driven boom-bust theory of economic cycle. Behind this mechanism is the change of the overall level of prices enabled by the changes in the use of credit in the payment system. The economic cycle, on the other hand, is precisely the time when the substantial changes in the price level may actually be observed.

Without having to subscribe to Mill's explanation of the economic cycle, it is worth to approvingly remind of Mill's main contribution to the income theory of money. In the present forms of payments systems which are heavily dependent on the use of credit, it is the change in the use of credit in the payment system which may substantially alter the volumes of monetary streams and consequently the overall level of prices. And Mill was right in claiming that there is always a lot of unused credit potential within any market economy, as well as that there sometimes appear to be observable broad scale patterns in the behaviour of credit in the payment system. Since the present monetary systems are more credit-dependent than what they used to be, these are definitely lessons worth to remember.

\section{Knut Wicksell: The Cumulative Process}

Knut Wicksell (1851-1926) is sometimes labelled the father of modern monetary theory and for good reasons too. The impact of his distinction between the natural and the market rate of interest was enormous, spanning from the direct influence over the Swedish, the Austrian and the Cambridge schools to the indirect influence in inspiring Friedman's introduction of the concept of natural rate of unemployment. With the realization that it really is interest rates rather than monetary aggregates what central banks target, and with the growth in awareness of the notion of endogenous money, Wicksell's popularity has increased lately. A useful introduction to Wicksell's thought is provided by Uhr (1951); his monetary ideas are discussed also in Festré (2006) and elsewhere. As the fundamental principles of the income theory of money have been explained beforehand, it will be straightforward for us simply to follow Wicksell's own exposition of the topic, which itself is clear enough.

Let us leave aside all the monetary policy implications as well as the whole real part of the problem concerning the determination of the so called natural (and normal) rate of interest, and let us concentrate on the monetary part of the story only. Let us remind the basic argument of the Wicksell's famed cumulative process and its bearings on the income theory of money.

Wicksell explains that with the completely flexible, purely account-based monetary system, the overall price level is ex-ante indeterminate. Yet, once set at a certain level, 
although the individual relative prices fluctuate, there is in principle no need for the general level of prices to move from its current position. On the contrary, general price level exhibits certain rigidity, and actively resists to being moved from the present position. Wicksell explains the so called "law of inertia" by rigidity of expectations on the entrepreneurs' part, who base their price expectations on the present level of prices (Wicksell 1935 [1906], IV.9, p. 196, Wicksell 1907, p. 216), perhaps simply expecting the prices to remain constant (Wicksell 1935 [1906], IV.8, pp. 185). The position of the overall level of prices is compared to that of "a cylinder or a ball on a rough plane": a position of a rather stable equilibrium somewhere on a plane, where it will be inclined to stay unless some strong enough force happens to move it elsewhere (Wicksell 1965 [1898], 7.B, pp. 93-5, Wicksell 1935 [1906], IV.9, p. 196-7, Wicksell 1907, p. 216).

The general price level ... is, on the assumption of monetary system of unlimited elasticity, in a position of, so to speak, indifferent equilibrium of the same kind as that of ball or cylinder on a plane, though somewhat restricted, surface: the ball does not move itself further, but from inertia and friction remains where it has been placed; if forces of sufficient strength to drive it from its position of equilibrium are brought into play, it has no tendency to resume that position, but if the forces which set it in motion ... cease to operate they will remain in a new and also indifferent position of equilibrium.

(Wicksell 1935 [1906], IV.9, p. 197)

The fact that the level of prices will tend to stay at the position where it came to end up is the reason why Wicksell calls his process cumulative. After the forces which were moving the prices have ceased to operate, the prices will not be returning to the previous level. The effect of the repetitive influence of the disturbing forces will thus be cumulative.

But what could these forces capable of shifting the whole price structure be? In complete accord with Tooke and Mill, it is more credit used in the payment system for Wicksell that can cause such a movement.

Wicksell starts his exposition of the cumulative process with the same premise as Mill, i.e. that it is the profit oriented behaviour of the entrepreneurs who employ new credit in the payment system that causes the overall level of prices to change. If there is an advantageous difference between current prices of inputs and expected future prices of outputs of production processes as compared to prevailing interest rate, entrepreneurs will be motivated to new credit-based purchases. Projects which appear to be able to deliver higher monetary paybacks than what is necessary to repay the loan of sufficient volume to finance the whole project are ex-ante profitable. The profit stems from the difference in ratios under which entrepreneurs can swap the present for the future monetary values and the ratio lenders require for the opposite swap. If there is a chance to obtain new loans for interest rates below the rate of profit of current investment opportunities, entrepreneurs will seize the opportunity and use the loans to exercise new nominal demand on the markets. This increase in monetary streams, on the other hand, will not fail to increase the market prices.

The availability of the unnaturally cheap credit is far from being a mere theoretical possibility for Wicksell. Rather than that it is a large scale phenomenon, a result of modern developments in banking and payment systems. Imagine a single bank which 
has monopolized all the payment business. Every single transaction is carried out as an accounting record crediting the balance of one costumer and debiting that of its payment counterpart. For such a bank it is virtually costless to augment the balance of a selected individual. It is thus profitable for the bank to create a balance for a customer in exchange for a promise of a later repayment with any positive interest rate no matter how low. The bank is thus motivated to provide loans at low interests while entrepreneurs are motivated to take the cheap loans as discussed above. The source of the profit is in fact a sort of present-time form of seigniorage income from the issue of monetary assets which is in this case divided between the bank and its loan customer, the division proceeding according to the height of the interest rate charged.

Wicksell goes on to explain that the same logic applies to the actual banking systems too. Indeed, if we imagine a closed banking system instead of a single monopolistic bank, the process still works the same. The only difference is in the need to take care of the mutual interbank positions by the means of moving the reserves around, reserves being nothing else but accounting records again, this time held with the clearing banks of the system. Even an open banking system operating within the whole-world economic system may be represented to work basically in this way. The only issue is that of the conversion of the balances in our banking system for some other assets, obvious examples being foreign currency, gold bullion or domestic cash. The reserve ratios consideration with respect to the option of the public to require these assets in exchange for their deposit balances comes into play here. Yet, if the exchange rate vis-à-vis the asset in question is left to float freely, or if there is an elastic supply of the asset in the case of need (a lender of last resort type of facility), even the reserve ratio considerations do not have to modify the process in any great respect. Without needing to get unnecessarily technical here, the point is that Wicksell's assumption of banks being able to augment the monetary circulation with cheap credits is quite a reasonable one not only for his times but it stays so even in the present-day monetary setups.

For more details on Wicksell's explanation of the ability of banks to "create credit without being limited by their own capital" and on the whole "cumulative process" see Wicksell (1965 [1898]), 3, pp. 26-7, 6.C, pp. 62-80, 7.A, pp. 81-7, 8, pp. 102-21, 9.B, pp. 134-56, Wicksell (1935 [1906]), IV.7-9, p. 168-208, Wicksell (1907).

From the point of view of the income theory of money, Wicksell is consciously expanding the approach of Tooke in explaining how an introduction of a new credit into the payment system can disrupt the current relation of the amounts of the real goods available to the volume of the nominal streams within the economy devoted the purchasing of the former. Since it is by the comparative intensity of these two streams that market prices are formed, the process must result in an increase of nominal prices. Creation of new credit on the part of the banks is the force pushing the prices up: a too low interest rate motivates the entrepreneurs to take more loans and to try to expand their activities, a rise of input prices immediately ensues with higher incomes and higher prices of consumption following shortly after. Once the force of the credit expansion ceases to operate, a new relation of the real and nominal streams is achieved and the overall level of prices remains to rest at the position it has reached.

It is my belief that this observation of Tooke's [the thirteenth point of Tooke's summary], or more precisely its first half [that incomes form the limiting principle of aggregate pric- 
es], does really provide a starting-point from which a theory of the value of money and prices can be developed.

(Wicksell 1965 [1898], 5, p. 45)

Every rise or fall in the price of a particular commodity presupposes a disturbance of the equilibrium between the supply of and the demand for that commodity. ... A general rise in prices is ... only conceivable on the supposition that the general demand has for some reason become, or expected to become, greater than the supply. ... [W] have accustomed ourselves, with J. B. Say, to regard goods themselves as reciprocally constituting and limiting the demand for each other. And indeed ultimately they do so; here, however, we are concerned with precisely what occurs, in the first place, with the middle link in the final exchange of one good against another, which is formed by the demand of money for goods and the supply of goods against money. Any theory of money worthy of the name must be able to show how and why the monetary or pecuniary demand for goods exceeds or falls short of the supply of goods in given conditions.

(Wicksell 1935 [1906], IV.6, pp. 159-60)

[T] he real cause of the rise in prices is to be looked for ... in provision by the Bank of easier credit[.]

(Wicksell 1965 [1898], 7.A., p. 87)

Wicksell the monetary theorist is best known for his exposition of the cumulative process. Rather late in his career, however, he introduced also another mechanism through which the price level might shift. The new mechanism, too, is in full accordance with the income theory of money. In the declining economy, say during the war times, the amount of real consumption goods available will decrease. Remembering the rigidity of prices we might expect nominal incomes and expenditures to decrease too to keep the overall price level stable. Yet what was actually observed during the World War I was reduction of the amounts of consumption goods coupled with a dynamic rise of its prices.

In compliance with the cumulative process it is new credit again which for Wicksell explains why a sudden fall in the volume of the real streams is not accompanied with appropriate drop in monetary flow too, and why an instant rise of prices is to be expected. Yet it is not expansion of entrepreneurs' loans this time but rather expansion of consumers' loans with the motivation to keep the real consumption level intact on the part of the consumers. Obviously, with less consumption goods around this goal cannot ultimately be achieved. Yet in the meantime the striving to retain the previous level of real consumption will cause the prices to rise. The monetary mechanism behind this is similar to the cumulative process: apart from the nominal income the nominal expenditures are augmented by new purchases on credit, only this time it is the consumer credit instead of the production credit which is responsible for the monetary expansion (Wicksell, 1965 [1925], I, pp. 199-205).

\section{Friedrich Wieser: The Price-payments for the Natural Values}

The Austrian economist Friedrich Wieser (1851-1926) was publishing his monetary ideas in about the same time as Wicksell and his ideas were very similar to Wicksell's 
too. Although he did not deliver any explanation of the changes of the general level of prices comparable in the elaboration to that of Wicksell, Wieser is more explicit about the overall structure of his monetary thoughts. Wieser's quotations may thus be used with advantage to round up the exposition of the early contributions to the income theory of money. In contrast to Wicksell, there are relatively few papers pertaining to the monetary theory of Wieser, being interested particularly in the reflections on Wicksell's explanation of the level of nominal prices I searched in vain.

Wieser, like Wicksell, acknowledges Tooke as a source of his monetary ideas (cf. Wieser 1904, p. 47). Instead of real goods Wieser is speaking of "natural values" which are exchanged against monetary streams. In the static economy the whole income is devoted to the purchase of these "natural values" and the overall price level may thus simply be obtained by relating the amount of incomes to the amount of "natural values" sold. These tenets of the income theory of money are present in Wieser's earlier monetary works (cf. Wieser 1904, p. 47, Wieser 1910, p. 516) already, the quotation I am using is from his main economic treatise Social Economy which was first published in 1914.

In the final analysis, the general price level is always determined by the sums of the values which make up the supply and demand in the market of natural values. On the side of the supply, these consist in all the natural values offered for sale. On the part of the demand we find the sums of money which are available for price payment. ... In a static economy, with neither progress nor retrogression, the money income is all used for the purchase of the consumption values necessary for the households. Thus we arrive at the brief expression that in a static economy, the general level of prices is determined by the newly produced natural consumption values on the one side and the monetary income on the other.

(Wieser, 1967 [1914], § 50., pp. 263-4)

The prices are determined in such a way that in the equilibrium of the static economy the total income corresponds exactly to the market value of all the goods offered, the one being, in fact, only a different way of expressing the other.

So long as the assumption of an undisturbed static economy is maintained, the principal movement of natural values must always balance with the auxiliary movement of pricepayments. More accurately, the sum of natural values offered by the participants in the process of production and acquisition must be equal to the sum of the money values at the disposal of buyers. ... No one can achieve the control of the money-form, who has not himself or through another turned in a corresponding quantity of natural values; no one can aspire to the control of the natural form, who has not surrendered a corresponding quantity of values in the money-form.

(Wieser, 1967 [1914], § 48., pp. 254, 256)

The actual position of the general level of prices is for Wieser, again the same as for Wicksell, ex-ante indeterminate. Yet, at any moment the present structure of nominal prices forms a historical given, and all the future development will necessarily have to start from these values as its basis.

The number of units of money to be used to express a unit of utility cannot be predetermined. They may be many of few. As a matter of fact, the value of money has been quite diverse both at various times and in different localities. It is invariably a matter that is historically determined. At any given time every economy finds the value of money deter- 
mined by prior development. During a new period the development proceeds continuously from this condition with historical precision. No matter what factors operate on the side of natural values or of money to influence the general price level, they always operate from the basis of preëxisting level of prices. The existing price structure is never changed simultaneously in all its parts. New facts affect only individual prices.

(Wieser, 1967 [1914], § 50., p. 264)

Like for Wicksell for Wieser, the overall level of prices offers resistance to its changes too, and again, it is the expectations founded on the current structure of the nominal prices that is the reason behind this.

The reappraisal of all the market-values to fit a new [monetary] standard, on the part of all buyers and sellers without exception, is an exceedingly complicated and laborious process which market is not overready to undertake.

(Wieser, 1967 [1914], § 52., p. 277)

[T] he need of money is also determined by the historical value of money. Those who speak of the appreciation of money misjudge the power of this historical value for which every business man makes allowance in calculating his costs and price.

(Wieser, 1967 [1914], § 53., p. 285)

The plan of all private and public economies is adjusted to the presupposition of the constancy of the value of money[.]

(Wieser, 1967 [1914], § 53., p. 282)

When explaining that no general overproduction can occur in an economy, as compared to a relative overproduction of a particular product, Wieser's monetary argument is similar to that of Say. Monetary system is viewed by Wieser as being flexible enough to allow for payments for the new products and new incomes dispersal without introducing any new difficulties - money is endogenous in this sense of the word.

Where natural values increase in adjusted proportions there will be no difficulty in arranging for payments without provoking crises. Money will circulate more rapidly as sales are more numerous than before. Means of credit payments will be better organized as all improvements in their organization have been made under the increasing pressure of the need of money.

(Wieser, 1967 [1914], § 53., p. 285)

As far as changes of the overall level of prices are concerned, since the prices are determined in the process of monetary flows meeting real flows of natural values, the general change of prices must be connected with a change of at least one of these magnitudes. Above all, prices will change if monetary streams are inflated with new money inserted into circulation while there is no immediate change on the real side of the economy. In this case a new demand appears on markets, and since supply does not respond, prices have to rise. Just to remind: demand for goods is a monetary magnitude in the ordinary course of a monetary economy while their supply is a real one. The other option is, of course, some changes in the stream of "natural values". Wieser gives his account of examples of both types of these forces that may be behind the general price level shifts (Wieser, 1967 [1914], § 53, p. 279-86). 
Considering the effect of credit on prices Wieser tacitly invokes the old Tooke's "real bills doctrine" that the new credit does not influence prices if it just mirrors the increase of the "natural values" and is used to facilitate its trade only. Other uses of credit within the payment system which he calls the "misapplication of the credit", on the other hand, lead to inevitable rise in prices (Wieser, 1967 [1914], § 53., p. 280-2).

Wieser's explanation of high prices of war economies is an example of the disruption on the real side of the economy. Price level will rise if the amount of consumption goods produced decreases relative to the nominal income. This is what happens when state redistributes incomes by taxes and diverts part of the income stream to unproductive activities (warfare) or, for that matter, activities which will deliver production only later (education). The nominal income stays the same, while the amount of goods has dropped: the rise in the present level of prices must result (Wieser, 1967 [1914], § 54., p. 289).

\section{Any Future for the Income Theory of Money?}

The income theory of money has its origins in the 19th century. Although its paradigm was very influential in the formation of the main monetary approaches of the first half of the 20th century, the approach now seems to have been nearly forgotten. What might be the reasons for this? Was the income theory of money perhaps superseded by a superior approach of the general equilibrium theory? Is there any future for the income theory of money at all?

The simplest answer is that economic theory undergoes repetitive shifts of paradigms during the history. Every paradigm brings to the fore specific theoretical framework and specific techniques, as well as its own set of questions. This is exactly what happened when the monetary theory of Keynes was modified into the real theory of NeoKeynesians who later gave way to the general equilibrium based approaches.

While general equilibrium theory is primarily interested in the resulting state of equilibrium and the relative prices which correspond to it, the income theory of money is, on the contrary, primarily occupied with the nominal prices and in the process before the equilibrium is reached, since this is precisely the time when the general level of prices is liable to move. The income theory of money is thus concerned with questions which the general equilibrium approaches simply cannot answer. What is happening until the equilibrium is reached, if indeed it is ever reached at all? How does the trade go on under non-equilibrium prices? Where did the nominal level of prices come from? This is just a sample of questions which the general equilibrium is either unable to answer at all or only can answer it by means of some artificial contrivances which are foreign to the original ideas of the theory.

If the income theory of money seems to be so instrumental in answering such core questions of monetary theory why it was not developed side by side with the other approaches currently in use then? The reasons seem to be pragmatic ones to me. It was already Cantillon who realized that these questions are too complex to allow for simple quantitative answers. The process of heterogeneous agents with different expectations exercising various degrees of monetary demands on diverse markets in the actual progress of time is intrinsically a complex one. With every change of individual expecta- 
tions or even only in the temporal sequence of individual's actions the result of the whole process might change. Not to speak about the whole supply side of the economic process one would have to superimpose to really gain the complete picture.

In the state of equilibrium with a fixed structure of prices, it obviously does not make any difference if the consumer decides on the amounts of various consumer goods to buy or on the amounts of money to spend at different consumer goods markets. Everyone is using up the whole of their income in the equilibrium, which means that all the budget constraints conditions just exactly hold. The monetary circulation picture of the income theory of money is only another way to imagine how the budget constraints actually operate in an economy. In equilibrium, in other words, the approaches are easily compatible.

If we move to the realm of economic dynamics, the whole picture changes dramatically. From the equilibrium point of view, all mutual loans of the participants played only an intermediate role and did not change anything as to the result of the whole exchange process. This is different from the point of view of the income theory of money, though. Anybody who perceives a profit opportunity in buying a greater quantity of some goods at present may do so by the means of credit. Since prices are allowed to change, this does matter this time. If people lack the ability to predict exactly the whole future development of prices, their information change during the process of the actual unravelling of the future. If all future transactions are not determined and irreversibly agreed upon at the present moment, the lifespan budget constraints never hold at any specific date either. With changing prices and changing information the operation of the monetary system may play its part in substantial shifts in individuals' perceptions of their real-terms budget constraints. This is in fact exactly what is happening on a large scale in any financial, banking, or monetary crises.

None of this can be treated properly by the general equilibrium approach family of models. While more than a century old income theory of money obviously did not solve all these problems, it might arguably still provide some healthy hints as to how to approach these inherently intricate theoretical problems of the dynamic monetary economy. In was mainly in some older monetary text that Wicksell was called the father of the modern monetary theory. While using this epithet in another occasion, it was pointed out to me by one reviewer that it seems a bit far-fetched now. Perhaps the father of the future monetary theory then?

\section{Conclusion}

The income theory of money explains how nominal prices are formed by interaction of nominal expenditures streams with real streams of goods sold. While various ideas leading to this theory were expressed already by John Law, Richard Cantillon, and JeanBaptiste Say, it is perhaps only Thomas Tooke whom we might want to call the originator of the theory. Within the Classical School of Political Economy, Tooke's ideas were further elaborated by John Stuart Mill. The theory reached a momentous formulation in the works of Knut Wicksell, and in many respects similar an exposition was delivered by Friedrich Wieser too. The recognition of the theory was impaired by the change of the mainstream paradigm as well as the surge in emphasis laid on the quantitative mod- 
elling in economics. Yet, there are certain fundamental questions of the monetary theory which the general equilibrium style models cannot cope with while the income theory of money, at least to a certain degree, can. This might give the theory some hope for the future.

\section{References}

CANTILLON, R. (1959 [1755]). Essay on the Nature of Trade in General, Engl. trans. published together with the original text Essai sur la Nature du Commerce en Général\}, London: Frank Cass and Company Ltd.

FESTRÉ, A. (2006). Knut Wicksell and Ludwig von Mises on Money, Interest, and Price Dynamics. Journal of the History of Economic Thought. 28(3), pp. 333-57.

LAW, J. (1705). Money and Trade Considered: With a Proposal for Supplying the Nation with Money. Edinburgh: Andrew Anderson.

MARGET, A. W. (1966 [1938-42]). The Theory of Prices. Reprinted. New York: Augustus M. Kelley.

MAS-COLELL, A., MICHALE, D. W., and GREEN, J. R. (1995). Microeconomic Theory. New York: Oxford University Press, ISBN-13 9780195073409.

MILL, J. S. (1965 [1848]). Principles of Political Economy with some of their Applications to Social Philosophy. London: Routledge \& Kegan Paul.

SAY, J.-B. (1880 [1803]). A Treatise on Political Economy, Philadelphia: Claxton, Remsen \& Haffelfinger.

SKAGGS, N. T. (2003). Thomas Tooke, Henry Thornton, and the Development of British Monetary Orthodoxy. Journal of the History of Economic Thought. 25, pp. 177 197.

SMITH, M. (2001). Endogenous money, interest and prices: Tooke's monetary thought revisited. Contributions to Political Economy. 20, pp. 31-55.

SMITH, M. (2002). Tooke's approach to explaining prices. The European Journal of the History of Economic Thought. 9(3), pp. 333-58.

TOOKE, T. (1844). An Inquiry into the Currency Principle. London: Longman, Brown, Green, and Longmans.

UHR, C. G. (1951). Knut Wicksell: A Centennial Evaluation, American Economic Review. 41(5), pp. 829-60.

WALRAS, L. (1977 [1871]). Elements of Pure Economics. Originaly published in Frech as Élements d'économie politique pure. Translated by William Jaffé 1954. Reprinted, New Jersey: Augustus M. Kelley.

WICKSELL, K. (1965 [1898]). Interest and Prices, A Study of the Causes Regulating the Value of Money. Originally published 1898 in German as Geldzins und Güterpreise, eine Studie über die den Tauschwert des Geldes bestimmenden Ursachen. English translation first published 1936. Reprinted. New York: Augustus M. Kelley. 
WICKSELL, K. (1907). The Influence of the Rate of Interest on Prices. The Economic Journal. 17(66), pp. 213-220.

WICKSELL, K. (1935 [1906]). Lectures on Political Economy, Volume Two: Money. Originally published 1906 in Swedish as Föreläsningar i nationalekonomi. English edition first published 1935. London: Routledge

WICKSELL, K. (1965 [1925]). The Monetary Problem of Scandinavian Countries. Originally published in Sweedish as: Valutaspörsmålet $\mathrm{i}$ de skandinaviska länderna. Ekonomisk Tidsskrift. 1925, pp. 205-222. English translation published as appendix in: WICKSELL, K. Interest and Prices, A Study of the Causes Regulating the Value of Money. First published 1936. Reprinted. New York: Augustus M. Kelley.

WIESER, F. (1904). Der Geldwert und seine geschichtlichen Veränderungen. Zeitschrift für Volkswirtschaft, Sozialpolitik und Verwaltung. XIII Band. Wien.

WIESER, F. (1910). Der Geldwert und seine Veränderungen. Schriften des Vereins für Sozialpolitik. 132 Band. Verhandlungen des Vereins für Socialpolitik in Wien, 1909. Leipzig: Duncker und Humblot, 1910, pp. 497-540.

WIESER, F. (1967 [1914]). Social Economics. Originally published 1914 in German as Theorie der gesellschaftlichen Wirtschaft. English translation first published 1927. Reprinted. New York: Augustus M. Kelley Publishers. 
